\title{
Aortic Endothelial Cells Regulate Proliferation of Human Monocytes In Vitro via a Mechanism Synergistic with Macrophage Colony-stimulating Factor Convergence at the Cyclin E/p27 ${ }^{\text {Kip1 }}$ Regulatory Checkpoint
}

\author{
Alexander S. Antonov, ${ }^{*}$ David H. Munn, ${ }^{\ddagger}$ Frank D. Kolodgie, ${ }^{\S}$ Renu Virmani, ${ }^{\S}$ and Ross G. Gerrity \\ *Department of Pathology, ${ }^{\ddagger}$ Department of Pediatrics and the ${ }^{\ddagger}$ Institute for Molecular Medicine and Genetics, Medical College of Georgia, \\ Augusta, Georgia 30912; and the ${ }^{\S}$ Armed Forces Institute of Pathology, Washington, DC 20306
}

\begin{abstract}
Monocyte-derived macrophages $(\mathrm{M} \phi \mathrm{s})$ are pivotal participants in the pathogenesis of atherosclerosis. Evidence from both animal and human plaques indicates that local proliferation may contribute to accumulation of lesion $\mathrm{M} \phi \mathrm{s}$, and the major $M \phi$ growth factor, macrophage colony stimulating factor (MCSF), is present in atherosclerotic plaques. However, most in vitro studies have failed to demonstrate that human monocytes/M $\phi$ s possess significant proliferative capacity. We now report that, although human monocytes cultured in isolation showed only limited MCSF-induced proliferation, monocytes cocultured with aortic endothelial cells at identical MCSF concentrations underwent enhanced (up to 40 -fold) and prolonged (21 d) proliferation. In contrast with monocytes in isolation, this was optimal at low seeding densities, required endothelial cell contact, and could not be reproduced by coculture with smooth muscle cells. Intimal $\mathrm{M} \phi$ isolated from human aortas likewise showed endothelial cell contact-dependent, MCSF-induced proliferation. Consistent with a two-signal mechanism governing $\mathrm{M} \phi$ proliferation, the cell cycle regulatory protein, cyclin $\mathrm{E}$, was rapidly upregulated by endothelial cell contact in an MCSFindependent fashion, but MCSF was required for successful downregulation of the cell cycle inhibitory protein $\mathrm{p} 27^{\mathrm{Kip} 1}$ before cell cycling. Thus endothelial cells and MCSF differentially and synergistically regulate two $\mathrm{M} \phi$ genes critical for progression through the cell cycle. (J. Clin. Invest. 1997. 99: 2867-2876.) Key words: atherosclerosis • macrophage • cell cycle regulation
\end{abstract}

\section{Introduction}

Monocyte-derived macrophages $(\mathrm{M} \phi \mathrm{s})^{1}$ are among the first cells to accumulate in early atherosclerotic lesions $(1,2)$. They may beneficially scavenge lipids and lipoproteins from fatty

Presented in part at the 67th Annual Meeting of the American Heart Association 14-17 November 1994 and was published in abstract form (1994. Circulation. 90(Part 2):I-571).

Address correspondence to Dr. Ross G. Gerrity, Dept. of Pathology, B7 152, Medical College of Georgia, Augusta, GA 30912. Phone: 706-721-2374; FAX: 706-721-4362.

Received for publication 2 October 1996 and accepted in revised form 28 March 1997.

1. Abbreviations used in this paper: $\mathrm{M} \phi$, macrophage; MCSF, macrophage colony-stimulating factor.

The Journal of Clinical Investigation

Volume 99, Number 12, June 1997, 2867-2876 streaks and regressing lesions (3-6), but their long-term presence may contribute to plaque progression (3, 7-10). Monocyte recruitment into arteries is controlled by a complex series of chemotactic (11-13) and adhesion (14-16) mechanisms. Additionally, there is evidence that the number of lesion M $\phi \mathrm{s}$ may be augmented by local proliferation (17-19). However, even the theoretical possibility of $\mathrm{M} \phi$ proliferation in human atherosclerotic lesions remains controversial, since human M $\phi$ s have, in general, been considered incapable of significant proliferation (discussed in 20-23). Recently, however, we and others have shown that human monocytes are capable of at least a limited amount of cell division before terminal differentiation in response to macrophage colony-stimulating factor (MCSF) $(24,25)$. Given that endothelial cells in atherosclerotic lesions produce $\operatorname{MCSF}(26,27)$, and its production is markedly stimulated by modified lipoproteins (28), MCSFinduced monocyte proliferation is potentially of considerable significance for the pathogenesis of atherosclerosis.

However, it was not clear from our previous studies that significant proliferation of human monocytes could occur under physiologically relevant conditions, since the increase in cell number as a result of proliferation was typically approximately fourfold, and more importantly, occurred only at high seeding densities (25). Such high densities have not been described in vivo, even in atherosclerotic lesions. Thus, for local proliferation to be seriously entertained as a mechanism of $\mathrm{M} \phi$ accumulation in atherosclerotic lesions, it seemed necessary that it be both more sustained in duration and occur at physiologically relevant (i.e., approaching clonal) seeding densities.

Our previous studies had focused on M $\phi$ s in isolation, which might not accurately reflect the situation occurring in vivo, since proliferation of hematopoietic-lineage cells is strongly influenced by interaction with neighboring cell types (29). We reasoned that the cell types that might influence M proliferation in atherosclerotic lesions were vascular endothelial and smooth muscle cells. Therefore, in this study we asked whether interaction with either of these cell types could support substantial proliferation of monocyte-derived M $\phi$ s at clonal seeding densities.

\section{Methods}

Microscopic examination of intact aortic segments

Human thoracic aortas with variable amounts of fatty streaking were obtained at autopsy (post mortem interval $<10 \mathrm{~h}$ ) from 21 individuals aged 15-34 yr. Two to three whole-thickness segments $\left(3-5 \mathrm{~cm}^{2}\right.$ surface area) were excised at random from each vessel, fixed in formalin, stained with $0.1 \% \mathrm{AgNO}_{3}$ for $10-15 \mathrm{~s}$, and cell nuclei counterstained with propidium iodide $(1 \mathrm{mg} / \mathrm{ml})$ for $10 \mathrm{~min}$. They were then mounted on glass slides and viewed by epifluorescence microscopy at 
545-nm excitation wavelength. Of these, 28 segments showed $>50 \%$ intact endothelial surface and were examined for this study. Other adjacent segments were prepared for transmission electron microscopy as previously described $(1,4)$.

\section{Aortic cell cultures}

Endothelial cells were isolated from thoracic aortic segments of 46 male trauma victims (20-64 yr) autopsied at $8-16 \mathrm{~h}$ postmortem and cultured as previously described $(30,31)$ with the single exception that after initial rinsing, aortic segments were preincubated for $20 \mathrm{~min}$ with $0.2 \%$ dispase in Medium 199 to remove adherent blood cells prior to isolation of endothelial and smooth muscle cells. After removing endothelial cells, the aortic segments were incubated for 10 min with $0.1 \%$ collagenase in Medium 199 to remove any residual endothelium, and smooth muscle cells were then isolated and cultured as previously described $(32,33)$. Growth medium for endothelial cells was M199 (Earle's balanced salt solution) supplemented with $20 \%$ fetal calf serum (Atlanta Biologicals, Inc., Norcross, GA), $25 \mathrm{mM}$ Hepes, $2 \mathrm{mM}$ L-glutamine, $1 \mathrm{mM}$ sodium pyruvate, $100 \mathrm{U} / \mathrm{ml}$ penicillin, $100 \mu \mathrm{g} / \mathrm{ml}$ streptomycin, $50 \mu \mathrm{g} / \mathrm{ml}$ endothelial cell growth factor (Boehringer-Mannheim Biochemicals, Indianapolis, IN), and $30 \mu \mathrm{g} / \mathrm{ml}$ heparin. Smooth muscle cells were cultured in the same growth medium but without heparin. All experiments were performed between passages 4 and 6 , at which time endothelial cell cultures were $>97 \%$ pure, and smooth muscle cultures $>99 \%$ pure, as assessed by immunostaining with von Willebrand factor and HHF-35 antibodies, respectively $(30,32)$.

Resident intimal $\mathrm{M} \phi$ suspensions were prepared from aortas with lipid-rich lesions using the procedure described above for smooth muscle cells. The suspensions were seeded on petri dishes, nonadherent cells removed by washing after $6-8 \mathrm{~h}$, and adherent cells (typically $>60 \% \mathrm{M} \phi$ s by HAM-56 staining) were harvested after $48 \mathrm{~h}$ and used for coculture experiments.

\section{Isolation of peripheral blood monocytes}

Peripheral blood monocytes were obtained from 26 healthy donors of either sex (24-38 yr) by leukocytapheresis (34) followed by counterflow centrifugation (35) under a protocol approved by our Institutional Review Board. These cells ( $>95 \%$ monocytes by morphology and cell surface markers) were either used immediately or cryopreserved in liquid nitrogen. Fresh and frozen monocytes behaved indistinguishably in all assays. In our hands, monocytes isolated using this method were functionally comparable to those isolated by other methods through a wide range of functional parameters $(11,25,34-38)$.

\section{Monocyte cultures}

Monocytes were cultured in isolation in the growth medium described above without heparin. Recombinant human MCSF (the generous gift of Genetics Institute, Inc., Cambridge, MA; $1.9 \times 10^{6} \mathrm{U} / \mathrm{mg}$ protein by bone marrow assay [39]) was added at $200 \mathrm{U} / \mathrm{ml}$ unless otherwise specified. To determine the effect of seeding density on proliferation and allow comparison with previous studies (25), monocytes were seeded at densities ranging from 7-30 $\times 10^{4} \mathrm{cells} / \mathrm{cm}^{2}$, as compared to $9 \times 10^{4}$ cells $/ \mathrm{cm}^{2}$ in previous studies (25). Other studies compared proliferation at optimal high $\left(25 \times 10^{4}\right.$ cells $\left./ \mathrm{cm}^{2}\right)$ and suboptimal low $\left(1-2 \times 10^{4}\right.$ cells $\left./ \mathrm{cm}^{2}\right)$ densities with proliferation on endothelial cell monolayers as described below.

\section{Coculture systems}

Confluent endothelial cell monolayers and multi-layer cultures of smooth muscle cells were used for all cocultures. Recombinant human MCSF was added at $200 \mathrm{U} / \mathrm{ml}$ unless otherwise indicated. In both monocyte cultures and coculture systems, growth medium was changed every $72 \mathrm{~h}$ by replacement of two thirds of the volume, with the addition of fresh MCSF.

Contact cocultures. Monocytes or aortic intimal M $\phi$ were added to endothelial or smooth muscle cell cultures to achieve an initial density of $1-2 \times 10^{4}$ cells $/ \mathrm{cm}^{2}$ after gentle washing at $2-4 \mathrm{~h}$ as previously described $(36,38)$, and cocultures were continued for up to $21 \mathrm{~d}$.
Monocytes were sequentially harvested and assayed for cell number or thymidine index. In other experiments, harvested monocytes were reseeded on fresh endothelial monolayers, smooth muscle cells, or plastic dishes and subsequently assayed for proliferation.

Noncontact cocultures. Monocytes $\left(1-2 \times 10^{4}\right.$ cells $\left./ \mathrm{cm}^{2}\right)$ were cultured on the bottom of multiwells and endothelial cells were separately grown to confluency on gelatin-coated glass coverslips. The coverslips were then placed, inverted, in the wells with monocytes but physically separated from them by $1-\mathrm{mm}$ thick spacer rings. Monocytes were sequentially harvested and assayed for proliferative activity.

Conditioned media. Conditioned media collected from endothelial cell cultures and from endothelial cell-monocyte contact cocultures at times when monocytes were actively proliferating (days 5-9) were added to monocytes grown on plastic, and proliferation was assayed at various intervals between days 1 to 14 to determine peak proliferation.

Inverted cocultures. In other experiments, monocytes were cocultured for $7 \mathrm{~d}$ in contact with endothelium on gelatin-coated glass coverslips. The coverslips were then inverted and placed in blank wells on top of 1-mm thick spacer rings. The majority of monocytes were loosely adherent and spontaneously lost contact with the endothelium and fell to the bottom of the well. These monocytes were assayed for proliferative activity $48 \mathrm{~h}$ after losing contact with the endothelium.

\section{Measurements of $M \phi$ proliferation}

In all long-term experiments, net proliferation was measured directly as increase in $\mathrm{M} \phi$ cell number. Cocultures were harvested with trypsin/EDTA, counted to determine total cell number, and the $\mathrm{M} \phi$ population identified using a cocktail of $\mathrm{mAb}$ against the $\mathrm{M} \phi$ surface markers CD11a, CD14, HLA-DR, and CD11c by FACS ${ }^{\circledR}$ analysis as previously described (25).

Where differences in the rate of proliferation were of interest, the percentage of monocyte/ $\mathrm{M} \phi \mathrm{s}$ in $\mathrm{S}$ phase was measured by quantitative autoradiography. Cells were labeled with $1 \mu \mathrm{Ci} / \mathrm{ml}$ of $\left[{ }^{3} \mathrm{H}\right]$ thymidine (NEN Products, Boston, MA; $6.70 \mu \mathrm{Ci} / \mathrm{mmol}$ ) for $24 \mathrm{~h}$, harvested by brief trypsin/EDTA treatment, cytocentrifuged onto glass slides, formalin fixed, and permeabilized with acetone. M $\phi$ s were stained with $\mathrm{mAb}$ against a M $\phi$ marker (CD11c or HAM-56) using a universal immunoperoxidase system (Bio Genex, San Ramon, CA). Slides were then coated with autoradiographic emulsion, dried, and exposed for $3-5 \mathrm{~d}$ at $4^{\circ} \mathrm{C}$. After development, 500 antibody-positive $\mathrm{M} \phi \mathrm{s}$ were counted on each slide, and scored for the percentage showing radioactively labeled nuclei (thymidine index). Positive cells were defined as those with $>20$ silver grains over the nucleus. Variation among triplicate cultures was typically $<5 \%$. To ensure that differences in thymidine index did not represent variations in activation kinetics, each treatment group was sampled at five to seven time points between days 3 and 21, and the peak levels were compared. All experiments involving cell counts or quantitative autoradiography were carried out in triplicate and subjected to statistical analysis using ANOVA.

In some experiments monocytes were cultured alone for 3-12 $\mathrm{d}$ in 96-well plates, then assayed for proliferation by $24 \mathrm{~h}$ total thymidine incorporation and liquid scintillation counting as previously described (25).

\section{Bioassay for MCSF activity}

Production of bioactive MCSF by endothelial cell cultures was assayed using MCSF-dependent 32D-cfms cells (40), a murine stem-cell line transfected with the human MCSF receptor (generous gift of $\mathrm{J}$. Pierce, National Institutes of Health). 32D-cfms cells in log-phase growth were washed free of MCSF and transferred to direct contact with endothelial cell monolayers. After $24 \mathrm{~h}$, proliferation was measured by thymidine incorporation as previously described (25). Proliferation in coculture was compared to a standard curve of 32D-cfms cells cultured in a titration of recombinant MCSF without endothelial cells. 


\section{Reverse transcriptase PCR}

RNA was prepared from cocultures and endothelial cells using commercial spin columns (RNEasy, Quiagen, Chatsworth, CA). For each sample, $1 \mu \mathrm{g}$ of total RNA was reverse transcribed using randomhexamer priming, and cDNA amplified by PCR (GeneAmp; Perkin Elmer, Branchburg, NJ). Primers for human MCSF were obtained from Clontech, Palo Alto, CA. PCR products were electrophoresed in $2 \%$ agarose gels and visualized with ethidium bromide.

\section{Immunoblot analysis}

M $\phi$ s (> $90 \%$ pure by FACS) were washed from cocultures, lysed, electrophoresed on $12 \%$ SDS-PAGE gels and transferred to PVDF membranes as previously described (34). Immunoblots were stained with mAb against human cyclin E (Santa Cruz Biotechnology, Santa Cruz, CA) or p27 ${ }^{\text {Kip1 }}$ (PharMingen, San Diego, CA), and developed with a commercial peroxidase-based chemiluminescence system (ECL; Amersham, Arlington Heights, IL).

\section{Results}

Clustering of subendothelial monocytes in human aortas. En face microscopy of $\mathrm{AgNO}_{3}$ /propidium iodide-stained segments of human aorta revealed multiple clusters (Fig. $1 A$ ) of mononuclear cells showing typical monocyte/M $\phi$ ultrastructure (Fig. $1 B$ ) located immediately subjacent to the endothelial monolayer, many of which were in intimate contact with the endothelium (Fig. $1 B$ ). Subendothelial $\mathrm{M} \phi$ aggregates ranged from small (10-20 cell) to large (200-400 cell) focal collections. Multiple $\mathrm{M} \phi$ clusters were observed in 28 out of 28 randomly selected segments of vessels obtained from 21 autopsy aortas, age 15-34 yr, indicating that the phenomenon was widespread even in thoracic aortas of young individuals without significant disease.

In vitro proliferation of monocytes in contact with endothelial cells. Monocyte proliferation was assessed in $>90$ independent experiments using multiple combinations of 46 endothelial cell donors and 26 monocyte donors. The effect of endothelial cell contact on $\mathrm{M} \phi$ proliferation described below was observed in every experiment.

Peripheral blood monocytes seeded on established endothelial cell monolayers did not injure or disrupt the monolayers, as assessed by phase-contrast microscopy (Fig. 2) or light microscopy after $\mathrm{AgNO}_{3}$ staining (not shown), and the two cell types were capable of sustained (up to $21 \mathrm{~d}$ ) interaction in vitro. When monocytes in contact with endothelial cells were exposed to MCSF, they demonstrated a dramatic and progressive increase in cell number (Fig. 2), typically resulting in a 10 20-fold expansion of the starting monocyte population (Fig. 3 $A)$. In contrast, $\mathrm{M} \phi \mathrm{s}$ cultured with optimal concentrations of MCSF but without endothelial cells showed minimal (less than twofold) expansion. This was true whether monocytes were cultured on tissue culture plastic (Fig. $3 \mathrm{D}$ ) or on smooth muscle cells (Fig. $3 \mathrm{C}$ ). Likewise, monocytes cultured in contact with endothelial cells but without exogenous MCSF remained viable, but their proliferation was dramatically reduced (Fig. 3 $B)$. Thus, both MCSF and endothelial cells were required for optimal proliferation and appeared to function together in a synergistic fashion.

The period of maximal proliferation (days 4-14) was characterized by high thymidine indices, indicating a rapid rate of cell division (Fig. 4). These results also confirmed the require-
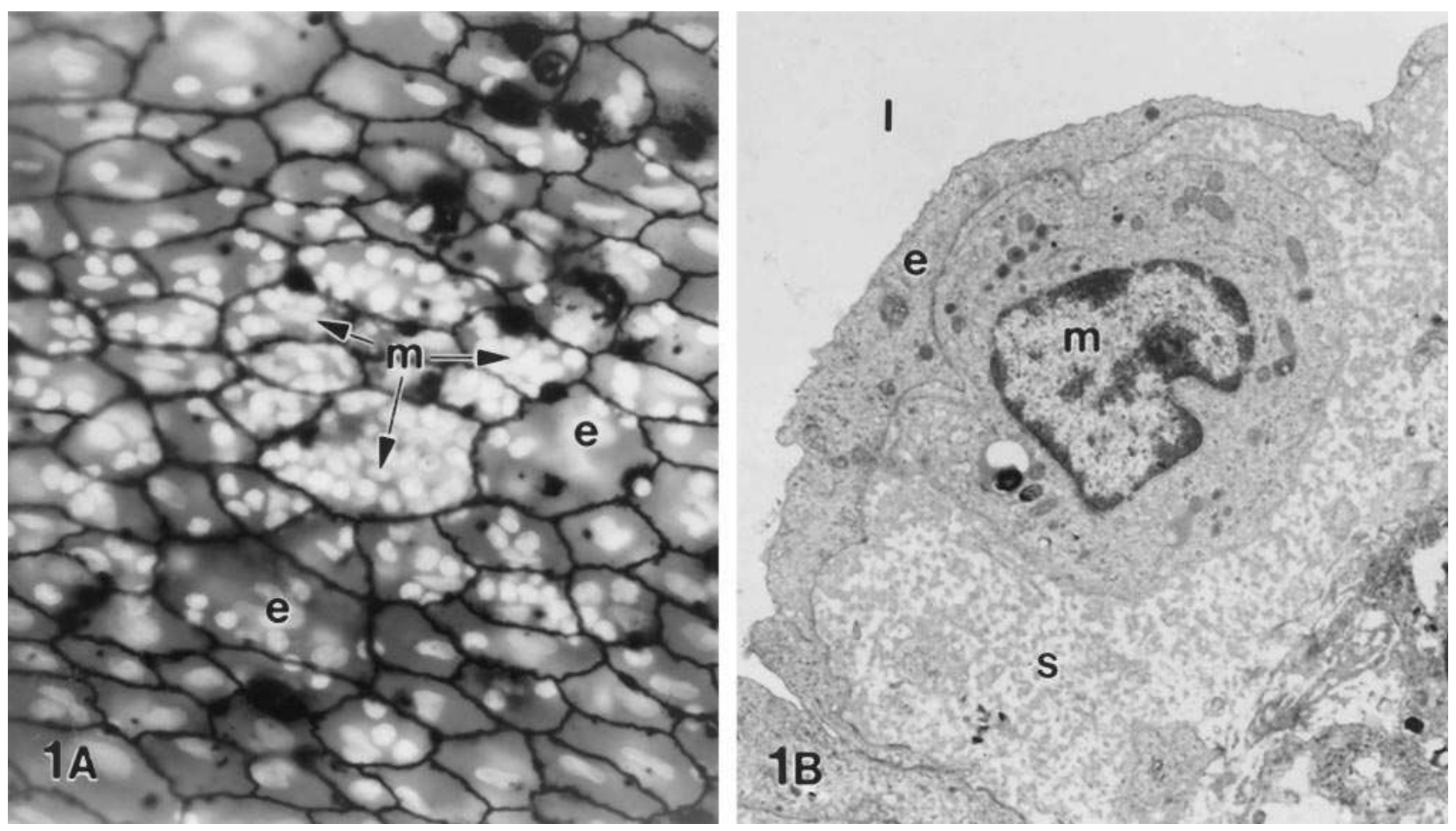

Figure 1. Subendothelial monocyte accumulation in human thoracic aorta. $(A)$ Silver stain shows borders of endothelial cells $(e)$; nuclei are revealed by propidium iodide fluorescence. Subendothelial monocytes are the small clustered nuclei $(m)$. $\times 140$. $(B)$ Transmission electron micrograph showing a monocyte $(m)$ in close apposition to an overlying endothelial cell $(e)$. The vessel lumen $(l)$ and subendothelial space $(s)$ are indicated. $\times 5,900$ 

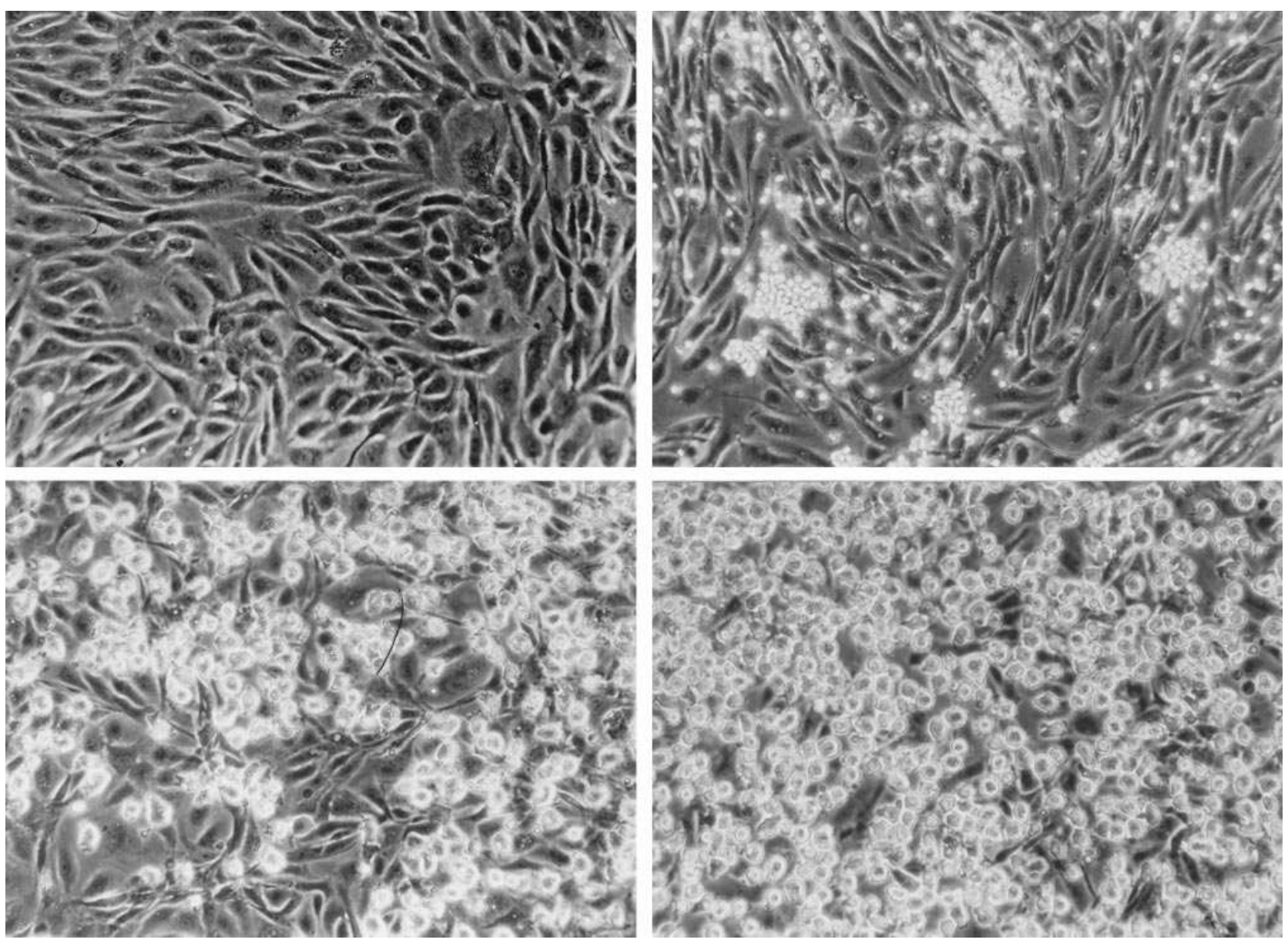

Figure 2. Phase-contrast photomicrographs of cocultures of monocytes and aortic endothelial cells in vitro. (Top left) Endothelial cells alone; contact cocultures at (top right) $24 \mathrm{~h}$; (bottom left) day 7; (bottom right) day 14 . All cultures received $200 \mathrm{U} / \mathrm{ml}$ MCSF. All photos $\times 66$.
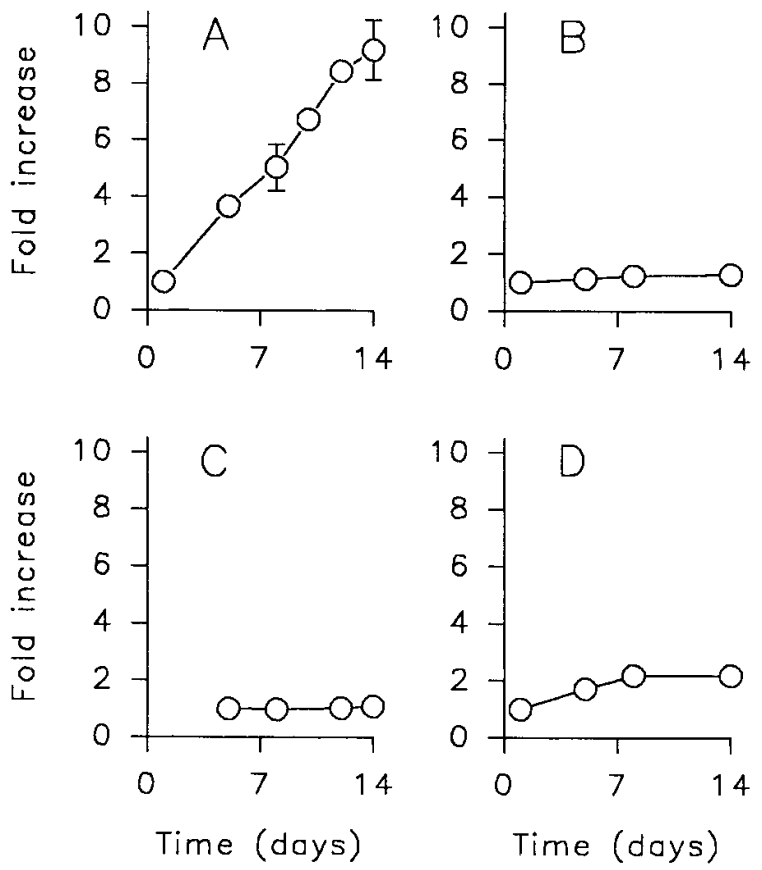

ment for both MCSF and endothelial cells to support significant proliferation and formally demonstrated the synergistic nature of the interaction (Fig. 4).

We have previously reported that human monocytes are capable of MCSF-induced proliferation in the absence of endothelial cells (25). The current studies extend these findings and demonstrate that optimal proliferation of monocytes cultured alone requires seeding densities even greater than previously described (25), essentially representing a confluent monolayer. In this study (Fig. $5 A$ ), we now show that the rate of DNA synthesis by monocytes cultured in isolation was directly correlated with the initial seeding density, even following appropriate normalization for starting cell number. Fur-

Figure 3. Coculture with endothelial cells enhances MCSF-induced monocyte proliferation. Monocytes were cultured for $14 \mathrm{~d}$ either $(A)$ on monolayers of endothelial cells with MCSF; $(B)$ on endothelial cells without MCSF; $(C)$ on smooth muscle cells with MCSF; and $(D)$ on tissue culture plastic with MCSF. Replicate cultures were harvested at serial time points, and $M \phi s$ quantified by cell counts and FACS analysis as described in Methods. Each curve representative of 3-6 similar experiments with each treatment condition. 
A
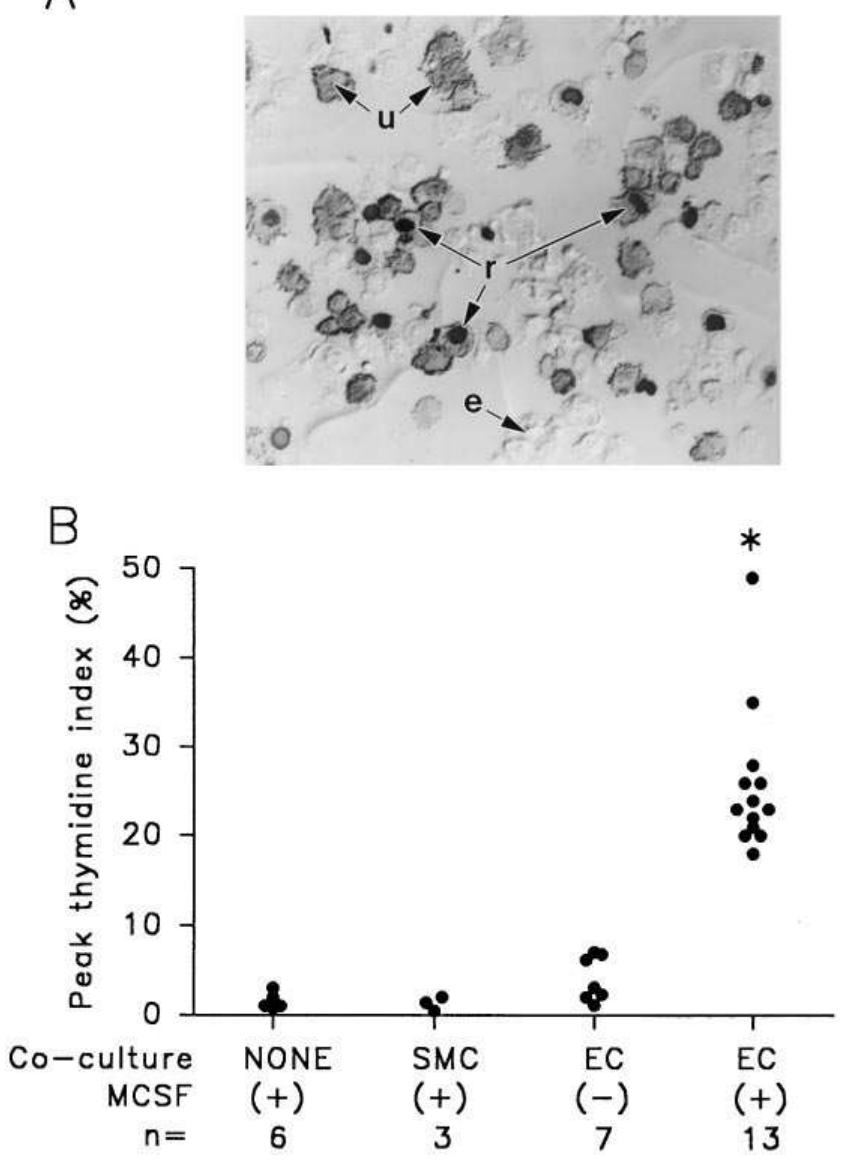

Figure 4. Synergistic effect of endothelial cells and MCSF on DNA synthesis. Cocultures were radiolabeled for $24 \mathrm{~h}$ with $\left[{ }^{3} \mathrm{H}\right] \mathrm{TdR}$. Monocytes were harvested and cytocentrifuge preparations were counterstained for the monocyte/M $\phi$ marker CD11c and processed for autoradiography. $(A)$ Representative photomicrograph showing both radiolabeled $(r)$ and unlabeled $(u)$ immunostained monocytes and unstained endothelial cells $(e)$. Nomarski differential interference contrast microscopy $\times 300$. (B) Peak thymidine index for monocytes cocultured either on endothelial cells $(E C)$, smooth muscle cells $(S M C)$, or tissue culture plastic, with (+) or without (-) MCSF as indicated. The asterisk indicates difference $(P<0.001)$ compared with all other treatment groups. The number of independent experiments $(n)$ for each condition is indicated.

thermore, even at optimal seeding density, proliferation of monocytes alone slowed after a few days (Fig. 5 B) and eventually stopped. This occurred regardless of initial seeding density and could not be prevented by refeeding with fresh medium or by subculturing. The total increase in cell number obtainable under these conditions was typically only three- to fourfold (Fig. $3 \mathrm{D}$ ), which is consistent with our previous reports and those of others $(24,25)$. Based on these observations, we wished to compare the proliferative capacity of monocytes cultured in isolation with those in contact with endothelial cells.

We first used the peak thymidine index technique described in Fig. 4, since, unlike total thymidine incorporation assays, it was not affected by low seeding density, differences in activation kinetics or the presence of contaminating endothe-
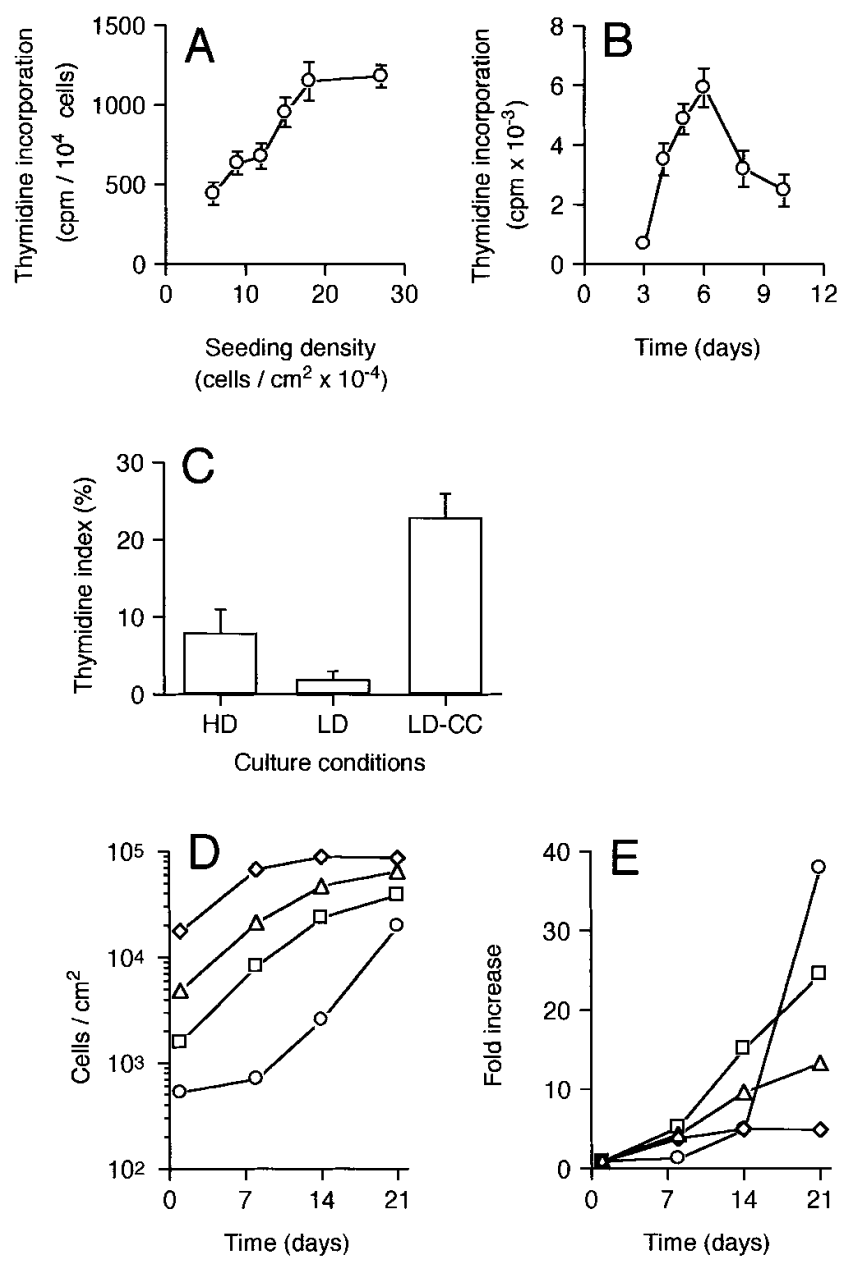

Figure 5. Effect of seeding density on monocyte proliferation. (A) Monocytes were seeded on tissue culture plastic at densities between $7-30 \times 10^{4}$ cells $/ \mathrm{cm}^{2}$ ). The cultures were then assayed for proliferation by thymidine incorporation and liquid scintillation counting on day 5. CPM have been normalized for initial seeding density (total cpm $\div$ number of cells seeded). (B) Monocytes were seeded on plastic at optimal density as determined in panel A $\left(25 \times 10^{4} \mathrm{cells} / \mathrm{cm}^{2}\right)$. Thymidine incorporation was measured daily. Representative of 5 experiments. $(C)$ Monocytes were seeded on plastic at high density $\left(\mathrm{HD}=25 \times 10^{4}\right.$ cells $\left./ \mathrm{cm}^{2}\right)$, on plastic at low density $\left(\mathrm{LD}=1-2 \times 10^{4}\right.$ cells $/ \mathrm{cm}^{2}$ ), or cocultured with endothelial cells at the same low density (LD-CC). Peak thymidine index was measured as in Fig. 4. Data shown represent the means of 4-11 separate experiments in each group. All values differ significantly $(P<0.05$ by ANOVA). $(D)$ Monocytes were cocultured with endothelial cells at densities of $2 \times 10^{4}$ (diamonds), $5 \times 10^{3}$ (triangles), $2 \times 10^{3}$ (squares), and $6.5 \times 10^{2}$ (circles) cells $/ \mathrm{cm}^{2}$. Total monocyte number was determined at various times after seeding (mean of triplicate wells, SD of $<5 \%$ has been omitted for clarity). 1 of 4 experiments. (E) Data from the experiment shown in $D$, reexpressed as fold increase over initial cell number. The symbols for the various seeding densities are the same.

lial cells. As shown in Fig. $5 C$, monocytes cultured alone at high seeding density $\left(25 \times 10^{4}\right.$ cells $\left./ \mathrm{cm}^{2}\right)$ demonstrated active proliferation (thymidine index of $4-11 \%$, comparable to other reports in the literature [24]). However, at low seeding densities (1-2 $\times 10^{4}$ cells $/ \mathrm{cm}^{2}$, used in our coculture system), monocytes in isolation showed little proliferation. At the same low 


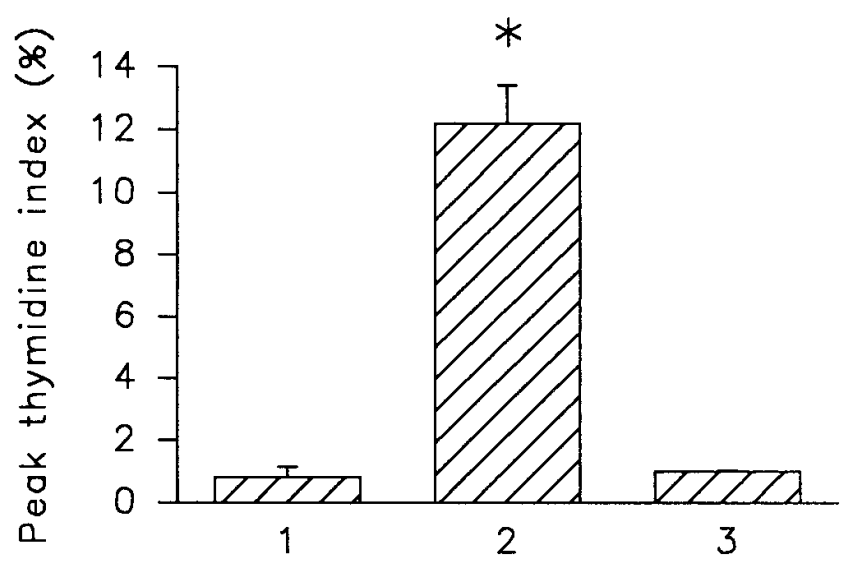

Figure 6. Proliferation of intimal M $\phi$ s induced by endothelial cell contact and MCSF. Intimal M $\phi$ s isolated from human aorta were cultured on plastic for $14 \mathrm{~d}$ (bar 1), or for $48 \mathrm{~h}$, then transferred either to established endothelial cell monolayers (bar 2) or to new culture dishes (bar 3) for $14 \mathrm{~d}$. Bars show peak thymidine index in a 14-d period. All groups received MCSF throughout. (* $P<0.05$ by ANOVA.) 1 of 3 similar experiments.

densities, however, monocytes in contact with endothelial cells proliferated vigorously.

We next asked whether endothelial cells could support monocyte proliferation at concentrations approaching clonal density. To ensure that cell division was not being offset by cell death in these long-term studies, we directly counted total monocyte number in addition to thymidine index. Monocytes were cocultured at densities between $2 \times 10^{4} / \mathrm{cm}^{2}$ and $5 \times 10^{2} / \mathrm{cm}^{2}$. As shown in Fig. $5 D$, even at the lowest seeding density, proliferation was brisk and sustained. Comparable data were obtained using thymidine index (data not shown). In marked contrast to monocytes cultured in isolation, however (Fig. 5 $A$ ), lower seeding densities permitted greater proliferation (Fig. 5 E). Also in contrast to monocytes cultured alone, cells at the lowest seeding density were still in log phase growth up to $21 \mathrm{~d}$.

Intimal M $\phi$ s proliferate in vitro. To determine whether fully differentiated tissue $\mathrm{M} \phi \mathrm{s}$ were able to proliferate, aortic intimal $M \phi$ s were cocultured with established endothelial cell monolayers. As shown in Fig. 6, neither the original M $\phi$ cultures nor harvested $\mathrm{M} \phi \mathrm{s}$ reseeded on plastic showed detectable MCSF-induced proliferation. However, intimal Mфs placed in contact with endothelial cells showed significant MCSFinduced proliferation (peak thymidine index of up to $12 \%$ ). Thus, the effect of endothelial cells on proliferation extended to mature, resident intimal $\mathrm{M} \phi \mathrm{s}$ as well as monocytes.

$M C S F$ production by endothelial cells. We next asked whether endothelial cells might enhance monocyte proliferation due to the production of additional MCSF. We first established the dose-response relationship between proliferation and MCSF concentration. As shown in Fig. 7, maximal proliferation in cocultures occurred at $100 \mathrm{U} / \mathrm{ml}$ (a dose identical to that eliciting maximal response of monocytes alone in high density cultures [data not shown]), and concentrations of MCSF higher than this had no additional effect. A similar plateau effect at $100 \mathrm{U} / \mathrm{ml}$ was evident at both 14 and $21 \mathrm{~d}$. We then quantitated production of biologically active MCSF by

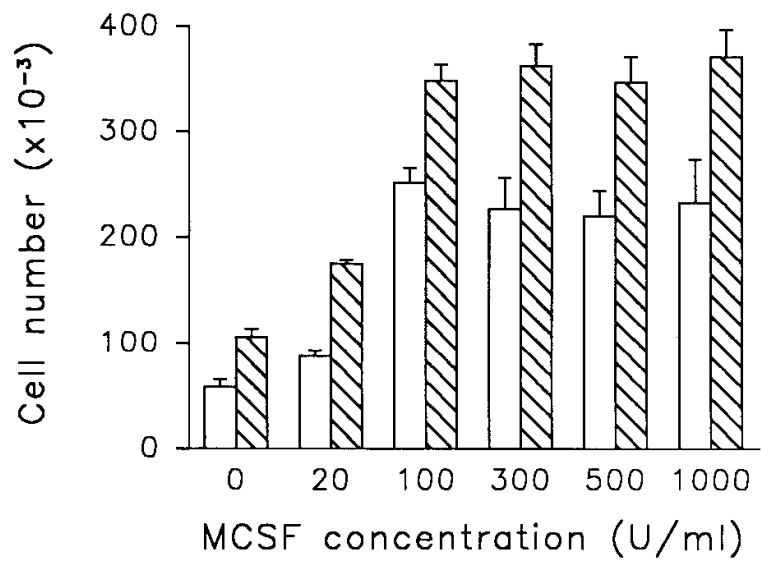

Figure 7. Dose-response to MCSF. Monocytes were cultured on endothelial cell monolayers (contact cocultures) for $14 \mathrm{~d}$ (open bars) or $21 \mathrm{~d}$ (hatched bars) in various concentrations of MCSF. When cultures were fed, fresh MCSF was added to maintain the concentrations shown. 1 of 3 experiments.

endothelial cells using a sensitive bioassay. The 32D-cfms reporter cells were placed in direct contact with endothelial cells during the assay to ensure that the action of any membranebound forms of MCSF (41) was also detected. As shown in Fig. 8 , contact with endothelial cells supported low but detectable proliferation by 32D-cfms cells, and, consistent with this, MCSF mRNA was detectable in endothelial cells and in cocultures by reverse transcriptase (RT)-PCR analysis. However, the actual amount of MCSF produced by endothelial cells was

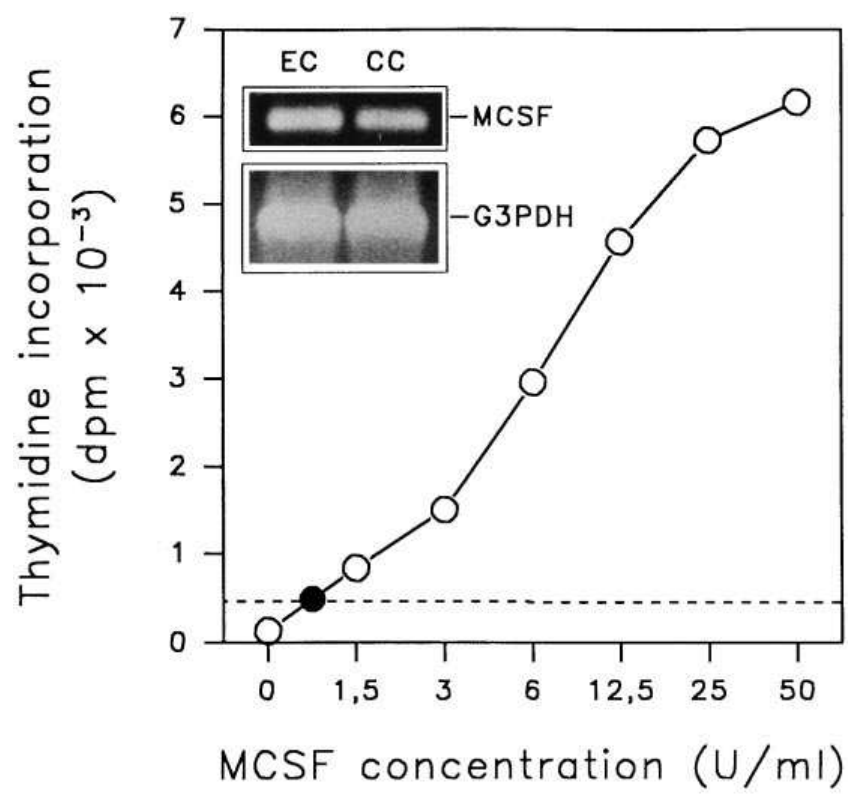

Figure 8. Production of biologically-active MCSF by endothelial cells. Proliferation of 32D-cfms in contact coculture with endothelial cells (solid circle) is compared to a dose-response curve of 32D-cfms cells to recombinant MCSF without endothelial cells (open circles). Inset confirms message for MCSF by RT-PCR using RNA from endothelial cell monolayers $(E C)$ and monocyte-endothelial cell cocultures $(C C) .1$ of 3 experiments. 
Table I. The Effect of Endothelial Cells on M申 Proliferation Is Contact Dependent

\begin{tabular}{llc}
\hline $\begin{array}{c}\text { Treatment } \\
\text { group }\end{array}$ & \multicolumn{1}{c}{ Culture conditions* } & Peak thymidine index \\
\hline 1 & Contact cocultures & $35.0 \pm 1.8^{\ddagger}$ \\
2 & Noncontact cocultures & $2.0 \pm 1.0$ \\
3 & Endothelial cell-conditioned medium & $1.2 \pm 0.7$ \\
4 & Coculture-conditioned medium & $0.8 \pm 0.6$ \\
5 & Growth medium & $3.0 \pm 0.5$ \\
\hline
\end{tabular}

* Monocytes were cultured for $14 \mathrm{~d}$ either: (1) in contact with endothelial cell monolayers; (2) separated from endothelial cells by a $1-\mathrm{mm}$ spacer ring; or without endothelial cells but (3) with conditioned medium from endothelial cell monolayers; (4) with conditioned medium from monocyte-endothelial cell cocultures; or (5) in growth medium alone. All cultures received MCSF. ${ }^{\ddagger} P<0.001$ versus all other groups by ANOVA. Representative of three similar experiments.

low compared with the exogenous cytokine (Fig. 7) and therefore could not account for the observed effect of endothelial cells on proliferation.

The effect of endothelial cells is contact dependent. When monocytes and endothelial cells were cultured in the same wells but physically separated from each other (noncontact cocultures), monocytes failed to proliferate, while those in contact with endothelium (contact cocultures) proliferated vigorously (Table I). Consistent with a contact-dependent mechanism, the effect of endothelial cells on $\mathrm{M} \phi$ proliferation was not transferable with conditioned medium from either endothelial cell cultures or contact cocultures (Table I). Even monocytes that had been actively proliferating in contact cocultures stopped dividing if they were harvested and reseeded on plastic or on smooth muscle cells (Fig. $9 A$ ) or if they lost contact with endothelial cells in inverted cocultures (Fig. $9 B$ ).

Endothelial cells and MCSF differentially regulate expression of cyclin $E$ and $p 27^{K i p 1}$. The above results suggested that endothelial cells influenced $\mathrm{M} \phi$ proliferation via a regulatory pathway distinct from that of MCSF. To test this hypothesis, we first examined the expression of cyclin $\mathrm{E}$, a critical regulator of the G1/S transition $(42,43)$. As shown in Fig. 10, $A$ and $B$, monocytes exposed to MCSF without endothelial cell contact, or while in contact with smooth muscle cells, only weakly expressed cyclin E. However, cyclin E was rapidly induced in monocytes by contact with endothelial cells, and this effect was not further enhanced by addition of exogenous MCSF (Fig. 10). Thus, in our system, a critical gene for MCSF-induced proliferation was upregulated more effectively by endothelial cell contact than by MCSF itself.

Despite this effect of endothelial cell contact on cyclin $\mathrm{E}$ in monocytes, MCSF was still required for efficient proliferation (see Fig. 4), implying an additional regulatory element. We therefore examined expression of $\mathrm{p} 27^{\mathrm{Kip} 1}$, an inhibitor of cyclin-cdk catalytic complexes that must be downregulated for cells to enter $\mathrm{S}$ phase $(44,45)$. We found that, in contrast to cyclin $\mathrm{E}$ expression, efficient downregulation of $\mathrm{p} 27^{\mathrm{Kip} 1}$ was highly sensitive to the presence of exogenous MCSF (Fig. 10, C and D). Thus, efficient entry of M $\phi$ s into $S$ phase required two independent signals converging at the cyclin E/p27 $7^{\text {Kip } 1} \mathrm{G} 1 / \mathrm{S}$ regulatory checkpoint.
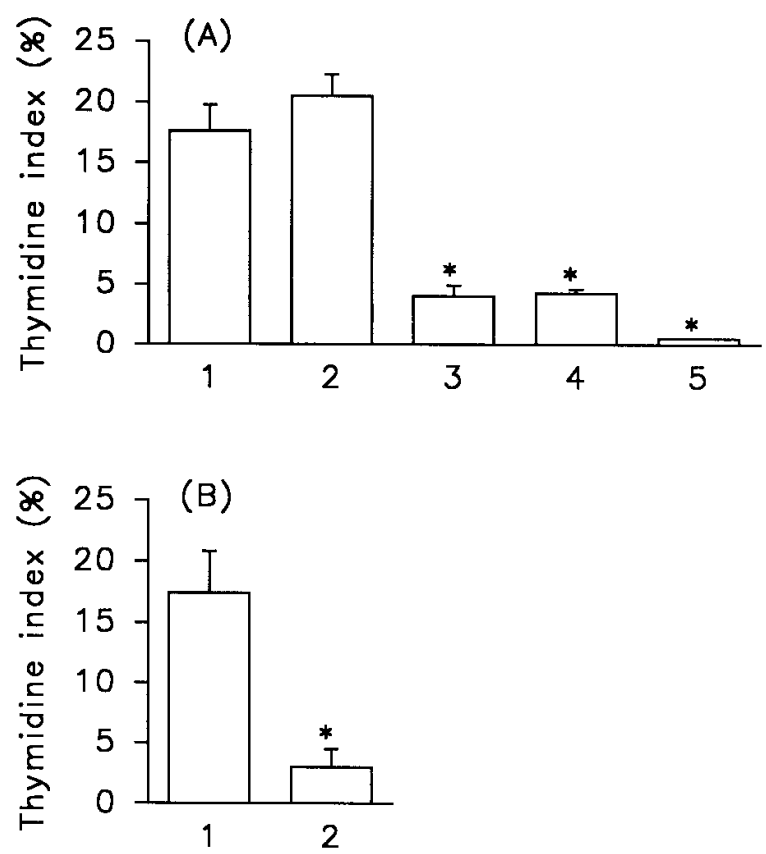

Figure 9. Proliferation requires sustained contact between monocytes and endothelial cells. $(A)$ Thymidine index was measured in monocytes from contact cocultures on day 9 (bar 1), or in monocytes cultured for $7 \mathrm{~d}$ in contact with endothelial cells, then harvested, reseeded and cultured for $48 \mathrm{~h}$ either on new endothelial cell monolayers (bar 2), smooth muscle cells (bar 3), or tissue culture plastic (bar 4 ). Monocytes cultured continuously on smooth muscle cell monolayers for $9 \mathrm{~d}$ served as a negative control (bar 5). All groups received MCSF throughout. $(* P<0.05$ compared to groups 1 and 2 by ANOVA.) 1 of 4 experiments. (B) Thymidine index was measured in monocytes cultured on endothelial cell monolayers (contact cocultures) grown on coverslips for $9 \mathrm{~d}$ (bar 1), compared to that in inverted cocultures in which coverslips were inverted onto $1-\mathrm{mm}$ spacer rings on day 7. Most monocytes were loosely adherent and spontaneously lost contact with endothelial cells and fell to the bottom of the dish. These were assayed for proliferation $48 \mathrm{~h}$ later (day 9$).\left({ }^{*} P<\right.$ 0.05 by ANOVA). 1 of 4 experiments.

\section{Discussion}

In this study we report two related findings with novel implications in the pathogenesis of atherosclerosis, as well as in inflammatory and immune responses. First, we show that human monocytes retain the capacity for extensive and sustained proliferation, starting from essentially clonal seeding densities. Second, we provide evidence that contact with vascular endothelial cells markedly enhances the proliferative response of both monocytes and intimal M $\phi$ s to their major physiologic growth factor, MCSF. We and others have previously shown that MCSF alone is sufficient to support proliferation of isolated monocytes if they are cultured at high density $(24,25)$, and the present results demonstrate that MCSF-induced proliferation is optimal at confluent seeding densities $\left(20-30 \times 10^{4}\right.$ cells $/ \mathrm{cm}^{2}$ ). Quantitatively, however, the proliferation achieved by monocytes alone in both the previous (25) and the current study was limited in both duration and the overall increase in cell number (less than fourfold), even at optimal densities and MCSF concentrations. More importantly, the conditions used are arguably artificial, since confluent monocyte monolayers 


\section{(A)}

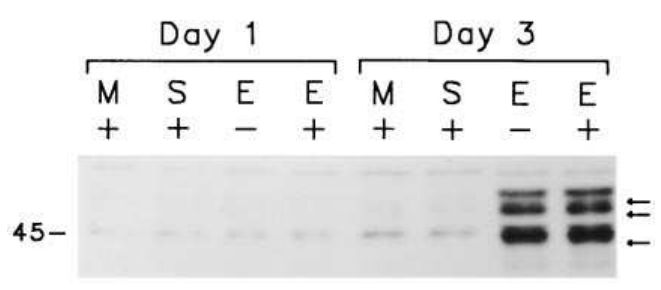

(B)
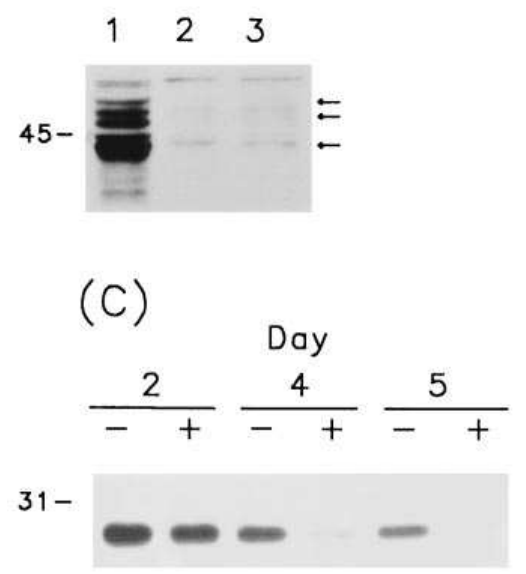

(D)

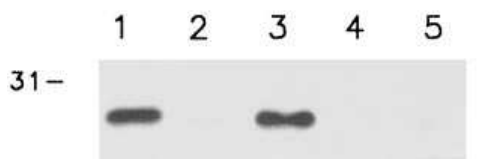

Figure 10. Independent regulation of cyclin E and $\mathrm{p} 27^{\mathrm{Kip} 1}$ expression. (A) Upregulation of cyclin E by endothelial cells. Monocytes were cultured either alone (lanes labeled $M$ ), on smooth muscle cells $(S)$, or on endothelial cells $(E)$ in the presence $(+)$ or absence $(-)$ of MCSF. Replicate wells were assayed for cyclin E expression by immunoblot on days 1 and 3 . The expected $M_{\mathrm{r}} 43$ band and $M_{\mathrm{r}} 52$ doublet are indicated by arrows. 1 of 5 experiments. $(B)$ Contactdependent regulation of cyclin E. Lane 1, monocytes in contact with endothelial cells; lane 2, monocytes separated from endothelial cells by $1 \mathrm{~mm}$ spacer ring; lane 3, monocytes alone. All cultures received MCSF and were harvested on day 5.1 of 3 experiments. (C) MCSFdependent downregulation of $\mathrm{p} 27^{\mathrm{Kip} 1}$. Monocytes were cocultured with endothelial cells in the presence $(+)$ or absence $(-)$ of MCSF. Expression of $\mathrm{p} 27^{\mathrm{Kip} 1}$ was analyzed by immunoblot on days 2,4 , and 5 . 1 of 4 similar experiments. $(D)$ Delayed addition of MCSF to cocultures resulted in rapid downregulation of $\mathrm{p} 27^{\mathrm{Kip} 1}$. Monocytes were cocultured with endothelial cells for $5 \mathrm{~d}$ (lanes 1 and 2) or $6 \mathrm{~d}$ (lanes 3 and 4) either with MCSF (2 and 4) or without MCSF ( 1 and 3). The monocytes in lane 5 were placed in coculture for $5 \mathrm{~d}$ without MCSF (as in lane 1) and then received MCSF for $24 \mathrm{~h}$ before harvesting on day 6.1 of 3 experiments.

do not occur in vivo. The current results show that, at low densities comparable to those observable in vivo, proliferation of monocytes cultured alone was minimal. However, contact with endothelial cells provided sustained (up to $21 \mathrm{~d}$ ) and markedly enhanced (20-40-fold increase in cell number) proliferation even at initial monocyte densities $>100$-fold less than those required when monocytes are cultured in isolation. We now describe an additional signal, supplied by contact with endothelial cells and acting synergistically with MCSF, which permits this extensive and prolonged monocyte proliferation starting from essentially clonal densities.

The effect of contact with endothelial cells was not merely to "sensitize" monocytes to MCSF. Rather, it supplied a signal distinct from that delivered by MCSF. The separate nature of this signal was best illustrated by the effect of endothelial cells on expression of cyclin E. Progression through G1 is governed by multiple cyclins, including the D-type cyclin family (46), which in Mфs is known to be directly regulated by MCSF (47). However, entry into $S$ phase is also dependent on expression of cyclin E $(42,43)$, and the effect of MCSF on cyclin E has not been established. In our system, cyclin $\mathrm{E}$ was not efficiently upregulated by MCSF itself, but was highly responsive to contact with endothelial cells. By itself, however, this did not result in significant proliferation due to the continued presence of $\mathrm{p} 27^{\mathrm{Kip} 1}$, a negative regulator that inhibits a broad range of cyclin/cyclin-dependent kinase complexes $(44,45)$. Downregulation of $\mathrm{p} 27^{\mathrm{Kip} 1}$ required the addition of exogenous MCSF.

This suggests a model of "two-signal" regulation. One signal, delivered by contact with endothelial cells, upregulates cyclin $\mathrm{E}$ and renders $\mathrm{M} \phi \mathrm{s}$ competent to proliferate in response to MCSF. The second signal, delivered by MCSF, induces downregulation of $\mathrm{p} 27^{\mathrm{Kip} 1}$ and subsequent progression into $\mathrm{S}$ phase. The presence of exogenous MCSF in this in vitro model is required to optimize proliferation and thus emphasizes the separate and distinct contributions of MCSF and endothelial cells. However, consistent with the low but detectable level of endogenous MCSF produced by endothelial cells (Fig. 8) and the modest proliferation observed even in the absence of exogenous MCSF (Figs. 3, 4, 7), we found that p27 ${ }^{\mathrm{Kip} 1}$ was eventually downregulated in cocultures without exogenous MCSF, although in a more variable and less predictable fashion (data not shown). Thus, even in a system intended to be dependent on recombinant MCSF, endothelial cells were still capable of supplying both signals needed to support M $\phi$ proliferation.

It might be argued that under normal circumstances the subendothelial space is not a site of prolonged residence for $\mathrm{M} \phi \mathrm{s}$, and therefore sustained contact with endothelial cells would not be expected to occur in vivo. However, in the specific case of early atherosclerotic lesions, endothelial cell-M $\phi$ contact and the progressive accumulation of $\mathrm{M \phi s}$ in the immediate subendothelial compartment has been well documented in animal models $(1,2,17,48-52)$, as has the predominance of $\mathrm{M} \phi \mathrm{s}$ in early human lesions (53-55). Using a novel en face technique, which allows microscopic examination of large areas of intima, we now demonstrate the common occurrence of subendothelial monocyte/M $\phi$ clusters in close contact with endothelium in thoracic aortas from young humans without significant disease. The presence of large numbers of intimal mononuclear cells in well-developed human atherosclerotic lesions has previously been demonstrated using this technique (56). However, our finding of such clusters in 28 of 28 specimens from 21 randomly selected aortas without overt disease suggests that $\mathrm{M} \phi$ residence in the immediate subendothelial space can be both frequent and prolonged in human aorta, since the phenomenon was not rare. The colony-like structure of many of these clusters suggested to us the possibility that they might arise from proliferation. Previous studies have 
shown that $\mathrm{M} \phi \mathrm{s}$ are the predominant proliferative cell type in human carotid plaques (19), and, in rabbit lesions, the majority of proliferating $M \phi s$ are found in the immediate subendothelial compartment (17). Based on these studies and our current findings, we propose that this compartment may provide a microenvironment in which $\mathrm{M} \phi$-endothelial contact can be combined with oxidized LDL-stimulated production of MCSF by endothelium (26-28), potentially resulting in the $\mathrm{M} \phi$ proliferation previously described in human vessels $(18,19)$.

The potential significance in atherosclerosis of a mechanism by which endothelial cells stimulate $\mathrm{M} \phi$ proliferation is considerable. We have previously demonstrated the specific recruitment of monocytes into lesion-susceptible areas during atherogenesis in swine, and the exit of lipid-laden $\mathrm{M} \phi$ foam cells from the same lesions $(1,4)$. Similar findings have been described by others in primate $(48,49)$ and rat $(50)$ models. On the basis of these studies, we postulated a protective role of the monocyte, resulting in the removal of lipid from lesions by the efflux of $\mathrm{M} \phi$ foam cells and their clearance by the reticuloendothelial system both in early atherogenesis $(1,4,51)$ and in the regression of fatty streaks and atherosclerotic lesions. If this protective hypothesis is correct, then one would expect to find mechanisms that enhance the availability, numbers, and intimal recruitment of blood monocytes under atherogenic conditions. Consistent with this, a number of such mechanisms, including M $\phi$ proliferation (17-19), have been described $(11-16,35,57)$. On the other hand, if the large numbers of $M \phi s$ generated in early atherogenesis were unable to clear sufficient lipid to prevent lesion progression, their continued presence could have significant deleterious lipid-accumulative, oxidative, cytotoxic, and growth-promoting effects (3, $7-10,58-60)$. Thus, whether $\mathrm{M} \phi$ proliferation is beneficial or pathogenic would depend on the balance between the levels of anti- and proatherogenic mechanisms achieved by these cells. In either case, significant proliferation of intimal $M \phi s$ could have a profound impact on the rate of progression of the lesion.

In the current study, we demonstrate a pivotal role for endothelial cells in regulating MCSF-induced M $\phi$ proliferation. Taken together with their other known roles in atherosclerosis, endothelial cells thus emerge as being capable not only of actively recruiting circulating monocytes and producing a potent growth factor for them but also of supplying additional signals which synergistically enhance their proliferative response to this growth factor. Endothelial cell-induced $\mathrm{M} \phi$ proliferation thus becomes a potentially significant mechanism of $\mathrm{M} \phi$ accumulation in developing atherosclerotic lesions.

\section{Acknowledgments}

We thank L. Donovan-Diener, K. Mackie, and D. Odom for expert technical assistance; N. Freeman for computer graphics and word processing; and R. Schaub for insightful discussion.

Supported in part by grants from the National Institutes of Health (R01 HL-46213 to R.G. Gerrity and K08 HL-03395 to D.H. Munn), and the Department of Pathology, Medical College of Georgia (Research Initiative Grant I-1-02 to R.G. Gerrity).

\section{References}

1. Gerrity, R.G. 1981. The role of the monocyte in atherogenesis. I. Transition of blood-borne monocytes into foam cells in fatty lesions. Am. J. Pathol. 103:181-190.
2. Simionescu, M., and N. Simionescu. 1993. Proatherosclerotic events: pathobiochemical changes occurring in the arterial wall before monocyte migration. FASEB J. 7:1359-1366.

3. Ross, R. 1993. Atherosclerosis: a defense mechanism gone awry. Am. J. Pathol. 143:987-1002.

4. Gerrity, R.G. 1981. The role of the monocyte in atherogenesis. II. Migration of foam cells from atherosclerotic lesions. Am. J. Pathol. 103:191-200.

5. Daoud, A.J., J. Jarmolych, J.M. Augustyn, and K.E. Fritz. 1981. Sequential morphologic studies of regression of advanced atherosclerosis. Arch. Pathol. Lab. Med. 105:233-239.

6. Daoud, A.S., K.E. Fritz, J. Jarmolych, and A.S. Frank. 1986. Role of macrophages in regression of atherosclerosis. Ann. NY Acad. Sci. 454:101-114.

7. Steinberg, D., S. Parthasarathy, T.E. Carew, J.C. Khoo, and J.L. Witztum. 1989. Beyond cholesterol: modifications of low density lipoprotein that increase its atherogenicity. N. Engl. J. Med. 320:915-924.

8. Clinton, S.K., and P. Libby. 1992. Cytokines and growth factors in atherogenesis. Arch. Pathol. Lab. Med. 116:1292-1300.

9. Ross, R., J. Masuda, E.W. Raines, A.M. Gown, S. Katsuda, M. Sasahara, L.T. Malden, H. Masuko, and H. Sato. 1990. Localization of PDGF-B protein in macrophages in all phases of atherogenesis. Science (Wash. DC). 248:10091012.

10. Penn, M.S., and G.M. Chisolm. 1994. Oxidized lipoproteins, altered cell function and atherosclerosis. Atherosclerosis. 108 (Suppl.):S21-S29.

11. Cushing, S.D., J.A. Berliner, A.J. Valente, M.C. Territo, M. Navab, F. Parhami, R. Gerrity, C.J. Schwartz, and A.M. Fogelman. 1990. Minimally modified low density lipoprotein induces monocyte chemotactic protein 1 in human endothelial cells and smooth muscle cells. Proc. Natl. Acad. Sci. USA. 87:51345138.

12. Berliner, J.A., M.C. Territo, A. Sevanian, S. Ramin, J.A. Kim, B. Bamshad, M. Esterson, and A.M. Fogelman. 1990. Minimally modified low density lipoprotein stimulates monocyte endothelial interactions. J. Clin. Invest. 85: 1260-1266.

13. Quinn, M.T., S. Parthasarathy, L.G. Fong, and D. Steinberg. 1987. Oxidatively modified low density lipoproteins: A potential role in recruitment and retention of monocyte/macrophages during atherogenesis. Proc. Natl. Acad. Sci. USA. 84:2995-2998.

14. Li, H., M.I. Cybulsky, M.A. Gimbrone, and P. Libby. 1993. An atherogeneic diet rapidly induces VCAM-1, a cytokine-regulatable mononuclear leukocyte adhesion molecule, in rabbit aortic endothelium. Arterioscler. Thromb. 13:197-204.

15. Smalley, D.M., J.H.-C. Lin, M.L. Curtis, Y. Kobari, M.B. Stemerman, and K.A.J. Pritchard. 1996. Native LDL increases endothelial cell adhesiveness by inducing ICAM-1. Arterioscler. Thromb. Vasc. Biol. 16:585-590.

16. Kume, N., M.I. Cybulsky, and M.A. Gimbrone. 1992. Lysophosphatidylcholine, a component of atherogenic lipoproteins, induces mononuclear leukocyte adhesion molecules in cultured human and rabbit arterial endothelial cells. J. Clin. Invest. 90:1138-1144.

17. Rosenfeld, M.E., and R. Ross. 1990. Macrophage and smooth muscle cell proliferation in atherosclerotic lesions of WHHL and comparably hypercholesterolemic fat-fed rabbits. Arteriosclerosis. 10:680-687.

18. Gordon, D., M.A. Reidy, E.P. Benditt, and S.M. Schwartz. 1990. Cell proliferation in human coronary arteries. Proc. Natl. Acad. Sci. USA. 87:46004604.

19. Rekhter, M.D., and D. Gordon. 1995. Active proliferation of different cell types, including lymphocytes, in human atherosclerotic plaques. Am. J. Pathol. 147:668-677.

20. van Furth, R., J.A. Raeburn, and R.L. van Zwet. 1979. Characteristics of human mononuclear phagocytes. Blood. 54:485-500.

21. Hocking, W.G., and D.W. Golde. 1979. The pulmonary-alveolar macrophage. Part I. (First of two parts.) N. Engl. J. Med. 301:580-587.

22. Golde, D.W., L.A. Byers, and T.N. Finley. 1974. Proliferative capacity of human alveolar macrophage. Nature (Lond.). 247:373-375.

23. Bitterman, P.B., L.E. Saltzman, S. Adelbeg, V.J. Ferrans, and R.G. Crystal. 1984. Alveolar macrophage replication: one mechanism for the expansion of the mononuclear phagocyte population in the chronically inflamed lung. J. Clin. Invest. 74:460-469.

24. Cheung, D.L., and J.A. Hamilton. 1992. Regulation of human monocyte DNA synthesis by colony-stimulating factors, cytokines, and cyclic adenosine monophosphate. Blood. 79:1972-1981.

25. Munn, D.H., and E. Armstrong. 1993. Cytokine regulation of human monocyte differentiation in vitro: the tumor-cytotoxic phenotype induced by macrophage colony-stimulating factor is developmentally regulated by interferon-gamma. Cancer Res. 53:2603-2613.

26. Clinton, S.K., R. Underwood, L. Hayes, M.L. Sherman, D.W. Kufe, and P. Libby. 1992. Macrophage colony-stimulating factor gene expression in vascular cells and in experimental and human atherosclerosis. Am. J. Pathol. 140: 301-316.

27. Rosenfeld, M.E., S. Yla-Hertualla, B.A. Lipton, V.A. Ord, J.L. Witztum, and D. Steinberg. 1992. Macrophage colony-stimulating factor mRNA and protein in atherosclerotic lesions of rabbits and humans. Am. J. Pathol. 140: 291-300.

28. Rajavashisth, T.B., A. Andalibi, M.C. Territo, J.A. Berliner, M. Navab, 
A.M. Fogelman, and A.J. Lusis. 1990. Induction of endothelial cell expression of granulocyte and macrophage colony-stimulating factors by modified lowdensity lipoproteins. Nature (Lond.). 344:254-257.

29. Gordon, M.Y. 1994. Physiology and function of the haemopoietic microenvironment. Br. J. Haematol. 86:241-243.

30. Antonov, A.S., M.A. Nikolaeva, T.S. Klueva, Y.A. Romanov, V.R. Babaev, V.B. Bystrevskaya, N.A. Perov, V.S. Repin, and V.N. Smirnov. 1986. Primary culture of endothelial cells from atherosclerotic human aorta. Part 1. Identification, morphological, and ultrastructural characteristics of two endothelial cell subpopulations. Atherosclerosis. 59:1-19.

31. Farber, H.W., A.S. Antonov, Y.A. Romanov, V.N. Smirnov, L.M. Scarfo, and D.J. Beer. 1992. Cytokine secretion by human aortic endothelial cells is related to degree of atherosclerosis. Am. J. Physiol. 262:H1088-1095.

32. Babaev, V.R., A.S. Antonov, O.S. Zacharova, Y.A. Romanov, A.V. Krushinsky, V.P. Tsibulsky, V.P. Shirinsky, V.S. Repin, and V.N. Smirnov. 1988. Identification of intimal subendothelial cells from human aorta in primary culture. Atherosclerosis. 71:45-56.

33. Babaev, V.R., A.S. Antonov, S.P. Domogatsky, and I.A. Kazantseva. 1992. Phenotype related changes of intimal smooth muscle cells from human aorta in primary culture. Atherosclerosis. 96:189-202.

34. Munn, D.H., A.C. Beall, D. Song, R.W. Wrenn, and D.C. Throckmorton. 1995. Activation-induced apoptosis in human macrophages: developmental regulation of a novel cell death pathway. J. Exp. Med. 181:127-136.

35. Gerrity, R.G., J.A. Goss, and L. Soby. 1985. Control of monocyte recruitment by chemotactic factor(s) in lesion-prone areas of swine aorta. Arteriosclerosis. 5:55-66.

36. Papapetropoulos, A., A.S. Antonov, R. Virmani, F.D. Kolodgie, D.H. Munn, N. Marczin, J.W. Ryan, R.G. Gerrity, and J.D. Catravas. 1996. Monocyte- and cytokine-induced downregulation of angiotensin converting enzyme in cultured human and porcine endothelial cells. Circ. Res. 79:512-523.

37. Munn, D.H., J.G. Pressey, A.C. Beall, R.S. Hudes, and M.R. Alderson. 1996. Selective activation-induced apoptosis of mature T cells imposed by macrophages: a potential mechanism of antigen-specific peripheral lymphocyte deletion. J. Immunol. 156:523-532.

38. Marczin, N., A. Antonov, A. Papapetropoulos, D.H. Munn, R. Virmani, F.D. Kolodgie, R. Gerrity, and J.D. Catravas. 1996. Monocyte-induced downregulation of nitric oxide synthase in cultured aortic endothelial cells. Arterioscler. Thromb. Vasc. Biol. 16:1095-1103.

39. Wong, G.W., P.A. Temple, A.C. Leary, J.S. Witek-Giannotti, Y.C. Yang, A.B. Ciarletta, M. Chung, P. Murtha, R. Kriz, R.J. Kaufman, et al. 1987. Human CSF-1: molecular cloning and expression of 4-kb cDNA encoding the human urinary protein. Science (Wash. DC). 235:1504-1508

40. Pierce, J.H. E. DiMarco, G.W. Cox, D. Lombardi, M. Ruggiero, L. Varesio, L.M. Wang, G.G. Choudhury, A.Y. Sakaguchi, P.P. DiFiore, et al. 1990. Macrophage-colony-stimulating factor (CSF-1) induces proliferation, chemotaxis, and reversible monocytic differentiation in myeloid progenitor cells transfected with the human c-fms/CSF-1 receptor cDNA. Proc. Natl. Acad. Sci. USA. 87:5613-5617.

41. Stein, J., G.V. Borzillo, and C.W. Rettenmier. 1990. Direct stimulation of cells expressing receptors for macrophage colony-stimulating factor (CSF-1) by a plasma membrane-bound precursor of human CSF-1. Blood. 76:13081314.

42. Ohtsubo, M., A.M. Theodoras, J. Schumacher, J.M. Roberts, and M. Pagano. 1995. Human cyclin E, a nuclear protein essential for the G1-to-S transition. Mol. Cell Biol. 15:2612-2624.
43. Dulic, V., E. Lees, and S.I. Reed. 1992. Association of human cyclin E with a periodic G1-S phase protein kinase. Science (Wash. DC). 257:1958-1961.

44. Coats, S., W.M. Flanagan, J. Nourse, and J.M. Roberts. 1996. Requirement of p27-Kip1 for restriction point control of the fibroblast cell cycle. Science (Wash. DC). 272:877-880.

45. Sherr, C.J., and J.M. Roberts. 1995. Inhibitors of mammalian G1 cyclindependent kinases. Genes \& Dev. 9:1149-1163.

46. Sherr, C.J. 1990. Mammalian G1 cyclins. Cell. 73:1059-1065.

47. Matsushime, H., M.F. Roussel, R.A. Ashmun, and C.J. Sherr. 1991. Colony-stimulating factor 1 regulates novel cyclins during the G1 phase of the cell cycle. Cell. 65:701-713.

48. Faggiotto, A., R. Ross, and L. Harker. 1984. Studies of hypercholesterolemia in the nonhuman primate. I. Changes that lead to fatty streak formation. Arteriosclerosis. 4:323-340.

49. Faggiotto, A., and R. Ross. 1984. Studies of hypercholesterolemia in the nonhuman primate. II. Fatty streak conversion to fibrous plaque. Arteriosclerosis. 4:341-356.

50. Joris, I., T. Nunnari, J.J. Krolikowski, and G. Majno. 1983. Studies on the pathogenesis of atherosclerosis. I. Adhesion and emigration of mononuclear cells in the aortas of hypercholesterolemic rats. Am. J. Pathol. 113:341-358.

51. Gerrity, R.G. 1989. Morphological development of the atherosclerotic plaque. In Atherosclerosis: A Pediatric Perspective. M.T.R. Subbiah, editor. CRC Press, Boca Raton, FL. 9-30.

52. Stary, H.C. 1976. Coronary artery fine structure in rhesus monkeys: the early atherosclerotic lesion and its progression. In Primates in Medicine. E.I. Goldsmith and J. Moor-Jankowski, editors. S. Karger, Basel. 359-395.

53. Stary, H.C. 1983. Macrophages in coronary artery and aortic intima and in atherosclerotic lesions of children and young adults up to age 29. In Atherosclerosis VI. G. Schettler and A.M. Gatto, editors. Springer-Verlag, New York. 462-466.

54. Wissler, R.W., and the PDAY Collaborating Investigators. 1994. New insights into the pathogenesis of atherosclerosis as revealed by PDAY. Atherosclerosis. 108 (Suppl.):S3-S20.

55. Wissler, R.W. 1995. The PDAY study in perspective. In Atherosclerosis X. F.P. Woodford, J. Davignon, and A. Sniderman, editors. Elsevier, New York. 30-39.

56. Romanov, Y.A., I.V. Balyasnikova, V.B. Bystrevskaya, T.V. Byzova, O.P. Ilyinskaya, A.V. Krushinsky, R.V. Latsis, E.L. Soboleva, E.M. Tararak, and V.N. Smirnov. 1995. Endothelial heterogeneity and intimal blood-borne cells. Relation to human atherosclerosis. Ann. NY Acad. Sci. 748:12-37.

57. Averill, L.E., R.C. Meagher, and R.G. Gerrity. 1989. Enhanced monocyte progenitor cell proliferation in bone marrow of hyperlipemic swine. Am. J. Pathol. 135:369-377.

58. Ishibashi, S., T. Inaba, H. Shimano, K. Harada, I. Inoue, H. Mokuno, N. Mori, T. Gotoda, F. Takaku, and N. Yamaga. 1990. Monocyte colony-stimulating factor enhances uptake and degradation of acetylated low density lipoproteins and cholesterol esterification in human monocyte-derived macrophages. $J$. Biol. Chem. 265:14109-14117.

59. Inaba, T., H. Shimano, T. Gotoda, K. Harada, M. Shimada, M. Kawamura, Y. Yazaki, and N. Yamada. 1993. Macrophage colony-stimulating factor regulates both activities of neutral and acidic cholesteryl ester hydrolases in human monocyte-derived macrophages. J. Clin. Invest. 92:750-757.

60. de Villiers, W.J.S., I.P. Frasier, D.A. Hughes, A.G. Doyle, and S. Gordon. 1994. Macrophage colony-stimulating factor selectively enhances macrophage scavenger receptor expression and function. J. Exp. Med. 180:705-709. 